\title{
Movimentos religiosos totalitários católicos: efeitos em termos de produção de subjetividade
}

\author{
Catholic's totalitarian movements: effects \\ in terms of subjectivity production
}

\author{
Sílvio José BENELLI
}

Abílio da COSTA-ROSA²

\section{Resumo}

Nossa pesquisa visa estudar a produção de subjetividade em instituições e estabelecimentos católicos dedicados à formação religiosa de seus membros. Neste artigo, tomamos como estudo o caso de um relato feito por um ex-membro do movimento Focolare. Procuramos descrever seu percurso formativo, sua integração e posterior abandono do grupo religioso. Operando basicamente por subtração e por meio de acréscimo de imaginário, a tecnologia empregada pelos movimentos religiosos integristas pode produzir uma subjetividade serializada de matiz fortemente fanático, sem espaço para a individualidade, para a iniciativa criadora, para a singularidade. Concluímos com algumas notas psicossociais relativas à compreensão psicanalítica do fanatismo religioso.

Palavras-chave: fanatismo; institucionalização; movimentos religiosos; produção de subjetividade; psicologia e religião católica.

\begin{abstract}
Our research aims to study the subjectivity production into Catholic institutions and environments dedicated to their members' religious formation. In this article, we had analyzed a report from an ex-Focolare member as a case study. We focused on describing his formative path, integration and latter desertion from such group. Basically by subtraction and by imaginary addition, the technology settled by this kind of integrative religious movement can produce a serialized subjectivity of deep fanatic shade, with no space for individuality, creative initiative, nor singularity. We have concluded with some psychosocial notes related to psychoanalysis understanding onto religious fanaticism.
\end{abstract}

Key words: fanaticism; institutionalization; religious movements; subjectivity production; Psychology and Catholic religions.

Estamos desenvolvendo uma pesquisa que visa entender a produção da subjetividade no contexto institucional de alguns movimentos e grupos religiosos católicos, tais como o Movimento Focolare (Lubich, 2003; Urquhart, 2002); Comunhão e Libertação (Rondoni, 1999; Urquhart, 2002),
Neocatecumenato (Blazquez, 1996; Cordonnier, 1995; Fernandez, 2004; Pasotti, 1999; Urquhart, 2002; Vicente, 1988) e Opus Dei (Ferreira, Lauand \& Silva, 2005; Perez, 1992; Prada, 1989; Rodríguez, 1993; Le Tourneau, 1985); tomamos, para isso, o Focolare como objeto específico de estudo.

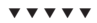

1 Doutorando de Psicologia Social, Instituto de Psicologia, Universidade de São Paulo. Rua Prof. Lúcio Martins Rodrigues, Travessa 4, Bloco 23, Cidade Universitária, 05508-900, São Paulo, SP, Brasil. Correspondência para/Correspondence to: S.J. BENELLI. E-mail: <sjbewelli@yahoo.com.br>.

2 Professor Doutor, Departamento de Psicologia Clínica e do Curso de Pós-Graduação em Psicologia, Faculdade de Ciências e Letras, Universidade Estadual Paulista. Assis, SP, Brasil. 
Neste artigo apresentamos um estudo sobre a condição de internado que experimenta um jovem que, ao ingressar no movimento religioso católico Focolare (Fondi \& Zanzucchi, 2004; Lubich, 2003; Oliveira, 1988; Silva, 2000), vive durante dois anos no contexto institucional de uma aldeia do grupo, onde realiza sua iniciação e passa a pertencer ao movimento.

O Movimento Focolare foi fundado por Chiara Lubich em Trento, Itália, em 7 de dezembro de 1943. Em 29 de junho de 1990, seus estatutos gerais atualizados foram aprovados por decreto do Conselho Pontifício para os Leigos da Igreja Católica, declarado como "associação de fiéis de caráter privado e universal de direito pontifício". Seu carisma é a "espiritualidade da unidade" e conta com mais de cem mil membros espalhados pelos cinco continentes, dividindo-se em 75 regiões. Seu presidente é Chiara Lubich, auxiliada por um co-presidente e por um conselho com sete membros. O Movimento Focolare é composto por famílias, jovens, sacerdotes, religiosos e religiosas de diversas congregações, além de bispos. As seções masculinas e femininas dos focolares consagrados na pobreza, castidade e obediência vivem em comunidades e constituem a base de sustentação do grupo. O Focolare tem diversas atividades de amplo alcance: "Famílias Novas", "Humanidade Nova", "Movimento Paroquial", "Movimento Diocesano","Jovens por um Mundo Unido", "Movimento Juvenil pela Unidade". Tem fortes incursões nos âmbitos da cultura, da educação, da economia e da política, contando também com poderosa atividade editorial. Possui 33"cidades de testemunho"e 63 centros Mariápolis para a formação social e espiritual de seus membros, em 46 países (Lubich, 2003, p.443).

A análise da instituição e dos processos empreendidos por ela se dá a partir dos dados de um caso que nos é apresentado em um relato escrito (Urquhart, 2002); daí a necessária recorrência a esse autor. No seu relato é perfeitamente possível distinguir o que são dados de experiência, vivência e observação, daquilo que é sua própria análise de tais dados. A riqueza de elementos descritivos nos parece um dos aspectos mais relevantes dessa obra. Trabalhamos a partir do seu depoimento pessoal, fazendo de sua experiência no movimento Focolare um caso singular (Aguiar, 2002, p.139). Nele procuramos verificar como funciona a instituição (grupo religioso), como é a vida no próprio estabelecimento e como o sujeito a experimenta, entende e responde a ela. Para isso, procuramos considerar tanto a realidade institucional do internato Focolare quanto a subjetividade que seu funcionamento promove, manifestando-se, essa, em dinâmicas psicológicas específicas. Os dados que tomamos como base para nossa análise são trazidos por alguém que se indispõe com o movimento, questionando seus princípios, métodos e efeitos. Isso é esperado, caso contrário poderíamos não ter relato algum; perguntamo-nos como poderia ser a descrição do movimento Focolare realizada por alguém que conseguiu aderir sem maiores questionamentos. Pensamos que isso talvez introduzisse variações nos dados, mas não deixaria de ser, do mesmo modo, um relato com forte implicação subjetiva de seu autor.

Partamos de alguns esclarecimentos sobre nosso método de análise: O que é um caso singular? É possível justificar uma reflexão e análise dos processos de funcionamento e de produção de subjetividade de um conjunto de instituições de formação religiosa com características semelhantes, a partir de um único relato, se concebermos a hipótese de que não se trata de caso isolado, um caso idiossincrático, mas, pelo contrário, de um caso singular (Aguiar, 2002, p.139). Para Rey, (1999), "El estúdio del caso singular adquiere su valor para la generalización por lo que es capaz de aportar a la cualidad del proceso de construcción teórica, no por su valor em términos de cantidad. Esta afirmación es expressión de uma comprención diferente del concepto de generalización..." (p.156). Para Lacan (1980, p.55) o que faz a singularidade de um caso é o caráter manifesto, visível, das relações em jogo; seu valor de evidência é superior à própria demonstração abstrata. Segundo esses autores, um caso é considerável singular na medida em que encerra as informações essenciais sobre as características básicas do fenômeno que procuramos compreender, e sobre os processos que aí estão em ação. O estudo de singularidade nos permite captar as determinações concretas constitutivas do fenômeno: "O conhecimento produzido a partir de um sujeito, uma escola, um grupo, constitui-se, pois, em uma instância deflagradora da apreensão e do estudo de mediações que concentram a possibilidade de explicar a realidade concreta" (Aguiar, 2002, p.139). Como veremos, o conjunto a que pertence a instituição que iremos analisar 
possui características e modo de funcionamento bastante congruentes com aquele que, já há bastante tempo, foi definido como instituições totais (Benelli, 2002, 2003a; Gofman, 1987).

Vejamos algumas características comuns entre o caso relatado por Urquhart (2002) e as instituições totais, que fundamentam nossa hipótese de que ele tem estatuto de caso singular. As características do funcionamento institucional, seus mecanismos de controle e administração dos internos, e a relação entre estes e a equipe dirigente são as mesmas das instituições totais (Benelli \& Costa-Rosa, 2003a, 2003b): isolamento do mundo exterior, supressão da privacidade dos indivíduos internados, segregação entre os gêneros, ausência de documentos escritos sobre objetivos e regulamento, controle exaustivo de todas as atividades e da rotina de cada um, entre outros; também está presente todo um conjunto de práticas e efeitos que designamos como processos de subjetivação que, do mesmo modo, são absolutamente congruentes com os das instituições totais: rituais de mortificação do eu e negação da história pregressa (desterritorialização social e subjetiva) e instauração de outra identidade radicalmente diferente da anterior, com características totalitárias; observaremos, ainda, a presença do retorno, nos institucionalizados, de uma série de efeitos subjetivos de natureza sintomática, expressos em performances radical e maciçamente identificatórias, como a atitude fanática. A propósito desse aspecto, é conveniente fazer já uma distinção entre identificação e identidade; a última supõe um mínimo de identificação e é a base para performances não imitativas, portanto singularizadas (Guyomard, 1996, p.12). Finalmente, constatamos um outro conjunto de performances sintomáticas que geram saídas agonísticas de natureza disruptiva do tipo "passagens ao ato" e mesmo fugas da instituição ou deserções da ordem nas instituições em que isso é possível.

Portanto, se ficar demonstrado que a instituição aqui estudada possui as características das instituições totais, visto tratar-se de uma instituição religiosa, cremos estar suficientemente indicada a possibilidade de sua representatividade, como caso singular, em relação a um conjunto amplo de instituições religiosas com características de instituições totais (Benelli \& Costa-Rosa, 2002; 2003a; 2003b). É nessa perspectiva que tomaremos o relato de Urquhart (2002) como descritivo das características da instituição "Movimento Focolare" e dos processos de subjetivação de que são objeto os sujeitos que nele aceitam ingressar.

Pensamos que esta análise já se justificaria pelas possibilidades de compreensão desse movimento particular, entretanto veremos que várias das suas características são extensíveis a outras instituições de natureza e funções similares, que têm sido designadas como movimentos neofundamentalistas leigos (Galindo, 1994; Martelli, 1995; Comblin, 1999; Brighenti, 2001; Libânio, 2000, 2003, 2005; Queiruga, 2003). Em resumo, tomamos como caso de análise uma instituição Focolare, pretendendo visualizar as características do Movimento Focolare e, com esse, apontamos na direção dos novos movimentos religiosos leigos neofundamentalistas (tais como "Movimento Comunhão e Libertação","Opus Dei","Movimento Neocatecumenato"; "Legionários de Cristo", entre outros.); a transversalidade da análise às três instâncias justifica-se, portanto, pelas características comuns de instituições religiosas totais.

Verificaremos também se nossa análise do caso em questão pode contribuir para a discussão da hipótese que é nosso ponto de partida, ou seja, que nesse tipo de instituição as modelagens da subjetividade têm características e efeitos particulares que, na literatura, são referidos ora de modo negativo, como rituais de mortificação do eu (Gofman, 1987; Benelli \& Costa-Rosa, 2003a), ora de modo positivo, como produção de subjetividade serializada (Guattari \& Rolnik, 1986). Ainda segundo essa hipótese, a instauração de tais processos subjetivos, que costuma dar-se pela supressão radical dos antigos modos de ser e sua substituição por modos novos, implica em performances do tipo sintomático, isto é, há um retorno da história e da singularidade recalcadas sob a forma de sofrimentos diversos e de modos de ser estereotipados, dos quais a performance fanática é apenas o efeito mais destacado. Podemos indicar desde já um exemplo desse retorno do recalcado: nesse tipo de instituição o indivíduo se forma formador; isso implica em que cada um terá que reproduzir em futuros candidatos os processos de que foi objeto. Nesse momento pode surgir uma forma de retorno do recalcado de modo denegatório (Freud, 1925), justamente na forma de comportamentos e ditames radicalmente estereoti- 
pados. Tudo se passa como se o indivíduo, agora na posição de formador, pudesse conjurar, através da repetição, na relação com seus formandos, os conflitos e angústias decorrentes do mesmo processo a que fora submetido e que em si mesmo permanecem não equacionados (Benelli \& Costa-Rosa, 2002, 2003b). Entretanto, feitas essas considerações sobre nosso método de estudo, não é demais assinalar que aceitamos perfeitamente que haja limites quanto à possibilidade de generalização do relato de Urquhart, primeiro porque acreditamos que, embora defendendo seu caráter de caso singular, nem por isso pensamos que fique superada por completo sua particularidade; segundo porque ele expressa a experiência subjetiva de processos objetivos e subjetivos. Porém devemos afirmar quanto ao segundo aspecto que, sendo a produção de subjetividade o foco de nossa análise, entendemos a subjetividade em sua dimensão objetiva, justamente na medida em que ela se transmite por palavras, ela só pode se expressar nas palavras, que permitem a objetividade possível para a subjetividade (Lacan, 1988).

\section{A experiência de noviciado de Urquhart no Movimento Focolare: dados relativos ao funcionamento institucional e os processos de modelagem subjetiva}

A partir do relato de Urquhart (2002), vejamos o que é um jovem que vive no estabelecimento formativo Focolare. Trata-se de um indivíduo que se sente chamado a consagrar a sua vida a Deus, como leigo participante de um grupo eclesial específico e que deve se preparar para assumir essa condição. O centro Focolare de Loppiano, Itália, é o local onde essa preparação é efetuada. O candidato se transforma em habitante de um mundo especial e peculiar, onde não apenas recebe uma formação específica, mas também assume uma condição humana muito particular: a de um indivíduo internado.

Na sua condição de internado, mesmo voluntário, o novato do grupo Focolare partillha de condições similares, sob vários aspectos, às dos internados num hospital psiquiátrico, numa prisão ou num colégio interno. A dinâmica da vida institucional nesses estabelecimentos apresenta pontos de impressionante coincidência. Será necessário ressaltar oportunamente suas diferenças também. O próprio internato Focolare pode ser visto como um colégio interno (Benelli, 2002, 2003a, 2003b), mas com objetivos mais específicos.

O movimento Focolare tem uma escola que recebe novatos já iniciados e que aderiram ao grupo em Loppiano, próximo a Florença, na Itália. Podemos dizer que ali os noviços (novatos) do movimento realizam seu noviciado (período preparatório à consagração religiosa, que culmina na emissão de votos religiosos e integração a determinada instituição religiosa). Trata-se de uma aldeia modelo do Focolare. Depois de dois anos ali, um novo membro permanente devidamente preparado e qualificado, por meio de uma consagração religiosa ao assumir os votos de pobreza, castidade e obediência, pode ser enviado para qualquer parte do mundo para missionar e difundir o movimento. Essa experiência e a profissão dos três votos normalmente significam a inserção permanente do indivíduo no grupo religioso. Mas no caso das instituições com características totalitárias esse processo de inserção parece estar longe de ser linear e pacífico.

A idéia de dedicar minha vida a Deus, trabalhando para Ele, me enchia de uma espécie de alegria e de sensação de aventura. Mas eu finalmente tinha perdido meu senso de orientação e também o controle de minha vida. Não era capaz de compreender ou analisar o que acontecera comigo em Loppiano, e só muito mais tarde iria conseguir: eu era a própria aniquilação e absorção de uma personalidade individual pela instituição. Quando começou esse terrível e deliberado processo de destruição, eu me senti mergulhar inexoravelmente no período mais negro de toda a minha vida (Urquhart, 2002).

$\mathrm{O}$ isolamento destaca-se como um elemento fundamental do processo formativo. Loppiano era utilizado para isolar totalmente os recrutas iniciados das influências do mundo exterior, para serem mais bem observados e modelados de acordo com as crenças, idéias, normas, hábitos e comportamentos prescritos pelo movimento.

O isolamento era total. Nós estávamos a cerca de uma milha da civilização. A população local era constituída de velhos camponeses analfabetos. Durante os dois anos que ali passamos, não assistimos a um programa de televisão sequer, nunca deitamos os olhos sobre um jornal. Desse modo, não sabíamos 
praticamente nada do que estava acontecendo no mundo lá fora, e, após algum tempo, isso parecia não ter a menor importância. ... Não havia livros, a não ser os escritos de Chiara Lubich e alguns outros sobre espiritualidade, publicados pela Città Nuova, a editora italiana do movimento. De qualquer modo, a leitura era desaprovada. Considerava-se estranho que alguém pudesse passar o tempo fazendo qualquer coisa sozinho, mas especialmente lendo. Durante todo o tempo que lá fiquei, li apenas dois livros (Urquhart, 2002).

Não havia rádio, televisão, filmes nem música "profanos", nem dias de folga ou sequer dinheiro para distrair ou contaminar os focolares em formação. Eram raras as saídas de Loppiano. O corte era radical para melhor efetivar o processo de ressocialização. Todos os anos havia a admissão de uns cinqüenta homens e mulheres, que eram segregados, mantidos à distância uns dos outros. Esses futuros líderes do movimento vinham de todos os países do mundo. A maioria deles tinha apenas uma idéia muito vaga do que se podia esperar - Loppiano não tinha nenhum documento escrito sobre as atividades do movimento (Urquhart, 2002).

O isolamento era para garantir que cada canto de nossas vidas estivesse sob completo controle de nossos superiores. Nossas mentes, atitudes e crenças tinham que ser radicalmente mudadas não através de um processo de aprendizado gradual ou do crescimento progressivo de uma convicção pessoal, mas através de um fluxo contínuo de uma torrente de conceitos e noções ao qual nós nos referíamos freqüentemente, de brincadeira, como sendo uma verdadeira lavagem cerebral (Urquhart, 2002).

A tendência antintelectual (Libânio, 2003, p.106) do movimento se manifestava agressivamente em Loppiano. Candidatos de notória orientação ou formação intelectual eram sempre destinados para a realização de trabalho braçal e servil.

Mas o ataque à razão era levado a extremos: eles nos impunham uma condenação total do pensamento. "Vocês pensam demais", era a resposta que recebíamos quando fazíamos perguntas. "Não pensem!", diziam-nos duramente nossos líderes. "Parem de raciocinar." Ou, de maneira mais radical ainda: "Corte sua cabeça fora." Quando alguém levantava algum problema a respeito do gênero de vida ou das idéias com que eles nos bombardeavam, recebia logo como resposta que"era um ser fechado","complicado", "um criador de problemas para si próprio" ou mesmo "vítima de algum complexo". O termo "mentalidade" era um dos motes, e aqueles que não estavam de acordo com o movimento eram acusados de ter uma mentalidade "velha". Eles nos aconselhavam a não tentar entender, mas a agir como eles mandavam, para "nos lançarmos para dentro da vida" em Loppiano, que a compreensão viria depois (sic)(Urquhart, 2002, p.61).

Em Loppiano, o trabalho era exclusivamente manual. Os noviços trabalhavam em uma fábrica de caminhões ou em empresas menores que fabricavam tapetes e artesanato em madeira. Os noviços também tinham que participar de campanhas para vender de porta em porta a revista do movimento (Urquhart, 2002, p.64). Havia um controle exaustivo de todas as atividades e da rotina de cada um, caracterizando intenso processo de arregimentação (Goffman, 1987, p.44), que indica a obrigação de executar a atividade regulada em uníssono com grupos de outros recrutas; e ainda um sistema de autoridade escalonada no qual qualquer pessoa da equipe dirigente tem o direito de impor disciplina a qualquer dos novatos, o que aumenta claramente a possibilidade de sanção:

Todos os cantos e recantos de nossas vidas eram minuciosamente controlados para prevenir qualquer espécie de reflexão ou de vida pessoal e para garantir que nunca ficássemos sozinhos. Éramos divididos em grupos de seis a oito pessoas de nacionalidade mista (a língua comum era o italiano) alojados em pequenos chalés pré-fabricados ou nos alojamentos da fazenda convertidos em apartamentos. Os espaços onde passávamos a maior parte do tempo eram supercongestionados, impedindo assim qualquer tipo de privacidade, embora o "pudor" no momento de vestir-se e das abluções fosse observado com extremo rigor (Urquhart, 2002, p.61).

Como podemos perceber, a tarefa da equipe dirigente do movimento é receber os novatos e aplicar-Ihes uma série de procedimentos que visam seu controle e modelagem subjetiva. De acordo com Goffman (1987, p.24) podemos denominá-los de processos de mortificação do eu, que costumam ser padronizados e incluir os seguintes aspectos: enclaustramento/seqüestração do indivíduo; processos de admissão que criam uma pasta pessoal que é continuamente alimentada com relatórios sobre o 
desempenho do internado; testes de obediência para conseguir a cooperação inicial do novato; despojamento dos bens, emprego e carreira; exposições contaminadoras físicas, sociais e psicológicas; o "circuito" (Goffman, 1987, p.40) que interliga todas as esferas da vida do internado no contexto institucional, utilizando um comportamento qualquer como índice do estado geral da sua condição pessoal; o sistema de privilégios (Goffman, 1987, p.49), por meio do qual se manipulam arbitrariamente algumas necessidades e satisfações do indivíduo, utilizando-as como prêmios concedidos em troca de obediência.

Podemos notar como se reproduzem aqui as táticas dos novos movimentos religiosos neofundamentalistas; eles adotam o princípio da eficácia de modo sofisticado e utilizam técnicas da psicologia social, de massa e de marketing: elevam o grau de insatisfação e desgosto para com a própria imagem até levar o indivíduo a romper com o"homem velho" e a aderir ao "homem novo" proposto pelo grupo. Palestras devidamente preparadas para produzirem esse efeito são proferidas diante de indivíduos deslocados de seu cotidiano onde podiam sentir segurança. Assistem, desprovidos de suas defesas habituais, à projeção de um quadro que retrata sua condição humana numa perspectiva demasiado negativa. Sua pequenez humana e moral é amplificada, de modo que o desejo de mudança brota quase que naturalmente. Então os indivíduos podem ingressar no grupo, aderindo à proposta apresentada, que já estava preparada anteriormente, com recursos e estruturas de apoio. A partir de técnicas comuns de recrutamento e formação de seus adeptos, esses grupos religiosos buscam com eficiência tornar o indivíduo totalmente dependente do movimento, passando a viver de sua doutrina: ele é despojado de sua autonomia e capacidade de reflexão e decisão pessoais.

Isso é algo que vivi de maneira muito intensa na experiência de "imersão total" em Loppiano. Assim como tínhamos que renunciar a todos os "apegos", de "perder" tudo, pessoas e coisas que nos fossem caras, também tínhamos de aprender a destruir nossos sentimentos. Sentimentos não têm a menor importância. Tínhamos que substituí-los pelos inúmeros preceitos que o movimento sugeria que aplicássemos obsessivamente no dia-a-dia. Estes
Chiara para "destruir o ego", "morrer para nós mesmos" e para "aniquilar" a nós mesmos ou nos tornarmos absolutamente"nulos". Todo pensamento devia ser removido, bem como as emoções que até então havíamos experimentado (Urquhart, 2002, p.75).

Vejamos outros efeitos da estadia de Urquhart em Loppiano:

Loppiano conseguiu isso com a maior eficiência, ao nos arrancar de nosso antigo mundo, criando um universo novo, totalmente irreal, de falsos valores. A sensação de desorientação que experimentei logo ao chegar era tão aguda que meus primeiros três meses ali foram um "branco" total. Um imenso vazio. Recordo aqueles meses ali mais exatamente como escuridão total. Eu tinha passado da atividade e das motivações da adolescência para uma juventude de monotonia, sem objetivo e sem sentido. O que me trouxe de volta foi a descoberta de que, para horror meu, eu passava o dia inteiro esperando a refeição seguinte. E não era porque a alimentação fosse frugal demais, não! Era simplesmente porque não havia absolutamente nada a esperar à frente. Minha ilimitada confiança anterior fora substituída por um estado de dúvida constante e uma sensação de que eu não tinha o menor valor. E isto não se aplicava apenas à dimensão espiritual; incluía também um colapso da fé em minha capacidade intelectual e prática (sic) (Urquhart, 2002, p.75).

Essa seria a tecnologia de modelagem típica de instituições e estabelecimentos totalitários, instrumentos implementados para modificar e transformar as pessoas. Nesses rituais de mortificação do eu situa-se uma forma de modelagem subjetiva por subtração. Porém, observando mais cuidadosamente, pode-se perceber que, nessas instituições de formação religiosa, há uma ênfase nos processos de modelagem por acréscimo. No movimento Focolare há afirmação clara da tradicional superioridade do celibato e da virgindade sobre o casamento e a prática sexual (Urquhart, 2002). Embora as reuniões públicas sejam sempre mistas, produzindo uma impressão de normalidade descontraída, a segregação de sexos predomina em todos os níveis do movimento. A liderança está nas mãos dos celibatários, embora haja também membros casados no movimento, mas com estatuto inferior (Urquhart, 2002). A homossexualidade deve ser tratada e"curada" por psiquiatras do movimento (Urquhart, 2002). 
Os temas espinhosos de sexo e sexualidade nunca eram mencionados durante os dois anos de curso em Loppiano. Fiquei convencido de que era o único ali a ter excitações sexuais que serviam para agravar ainda mais a sensação de desgosto e alienação. Talvez estivéssemos todos no mesmo caso. ... Para os focolarini, o celibato era uma espécie de miraculosa castração espiritual. Afinal de contas, nós não éramos seres de carne e sangue; nós éramos anjos. ... estágio preferido do desenvolvimento emocional ... parecia ser a pré-adolescência....Eles estimulavam o comportamento infantil... . Eles tinham medo da complexidade das emoções adultas, e as rejeitavam. Nesse estágio de desenvolvimento estacionário, o sexo não tem nenhum espaço e, por conseguinte, nunca precisa ser mencionado (Urquhart, 2002).

Nos processos de modelagem subjetiva por acréscimo, os ideais da instituição e do grupo parecem funcionar como fatores decisivos, pois fornecem os contornos de uma identificação do tipo massa-líder, em que ocorre a substituição de um arcabouço subjetivo singular por outro coletivo de características altamente idealizadas (Freud, 1921). Parece ser em torno dessa idealização que se dá a abdicação voluntária dos antigos modos de ser e pensar, e sua substituição pelos novos.

Quanto às relações interpessoais, a técnica utilizada no Focolare era "dividir para reinar". Nas palestras oficiais, a orientação era para que se evitassem as "amizades particulares", de modo a manter à distância pessoas das quais se gostasse:

Uma prática destinada a evitar a formação de "laços" ou "apegos" era a de ficar constantemente "embaralhando" os grupos, inserindo neles "cartas" diferentes. Depois de ter passado alguns meses juntos, sem que ninguém nos prevenisse, uma noite, antes da sopa, a gente ouvia a leitura de uma lista que anunciava as novas configurações e tínhamos então que embalar todos os nossos pertences e fazer a mudança para novos grupos. Estas mudanças eram concebidas de tal maneira que ninguém iria ficar em companhia de um antigo colega de quarto (Urquhart, 2002, p.61).

Por meio dessa espécie de desterritorialização social e afetiva era possível evitar um fenômeno comum em instituições totais (Goffman, 1987, p.159): o processo de confraternização, no qual o grupo dos internados se une, desenvolvendo apoio mútuo e uma cumplicidade como resistência a um sistema que os forçou à intimi- dade numa única comunidade igualitária de destino. No claustro, a solidariedade costuma produzir uma infinidade de grupos primários no estabelecimento: "panelinhas", facções, inclusive ligações sexuais mais ou menos estáveis, chegando até a formação de pares, por meio dos quais dois internados podem passar a ser reconhecidos como "amigos" ou "casal" pelos demais companheiros (Benelli, 2003b).

A institucionalização da existência humana tende a torná-la insípida, pasteurizada, num processo de achatamento e uniformização de toda e qualquer singularidade. $\mathrm{O}$ indivíduo tem mecanismos de resistência para enfrentar os poderosos efeitos que a máquina kafkiana produz:

Os dilemas morais apareciam freqüentemente com muita clareza quando eu acordava no meio da noite. Situações que pareciam confusas e tenebrosas durante o dia tornavam-se de repente claras como cristal. Quando eu acordava à noite em Loppiano, os pensamentos e as sensações que se apoderavam de mim eram sempre os mesmos: "Que diabos estou fazendo aqui?" Mas esta clareza iria desaparecer ao primeiro raio de sol da manhã seguinte, e eu voltaria para aquilo que considerava a realidade. Como tudo que anteriormente havia tido importância para mim tinha sido esvaziado, só restava uma sensação esmagadora: nada tem importância! (Urquhart, 2002, p.75).

Nada mais tinha importância, exceto o próprio movimento. Não restando nada ao indivíduo, ele passa a ter uma existência vicária, vivendo apenas por meio das lutas, projetos e triunfos da organização. Perdendo sua existência singular, só lhe é permitida uma existência institucional, desprovida de singularidade. Os dados de Urquhart (2002) indicam que os membros do movimento Focolare vivem um processo de repressão intensa de conflitos, contrariando importantes necessidades pessoais. Vivendo num estado de frustração crônica, podem ter sua saúde física e psíquica abaladas. A tentativa de supressão da singularidade subjetiva, do desejo, da sexualidade e das emoções pode falhar e conflitos inconscientes mantidos silenciosos, a duras penas, podem eclodir manifestando-se por meio de sintomas como ansiedade, depressão ou excitação motora excessiva. Efeitos típicos da institucionalização da vida humana costumam ser sintomas de tensão extrema, de estresse, medo e culpa. Urquhart (2002) descreve vários exemplos de tais efeitos. 
Evitar a formação de "laços" ou apegos era, portanto, aparentemente, uma forma da instituição e seus dirigentes se defenderem de possíveis ações, por parte dos internos, de contraposição ao instituído. Outro elemento que facilitava bloquear a confraternização entre os recrutas "noviços"era a ênfase dada à mudança constante e à incerteza: "o horário diário ou semanal era alterado constantemente. Freqüentemente planos eram mudados em cima da hora. De tempos em tempos, tínhamos de deixar o jantar no meio para atender a uma convocação para uma reunião no salão principal" (Urquhart, 2002).

Essa arbitrariedade e imprevisibilidade permanentes, que resultavam em constante desorientação ambiental, eram suficientes para sabotar as diversas estratégias de ajustamento secundário (Goffman, 1987, p.159) de que o grupo dos noviços poderia lançar mão no estabelecimento para se defender da desterritorialização social e subjetiva a que era submetido.

Neste ponto parece oportuno agregarmos algumas observações de Pereira, que sublinha esta característica importante das instituições totais: o temor paranóico do retorno, contra a instituição e a equipe dirigente, das pulsações instituintes recalcadas no conjunto dos internos pelo próprio processo formativo, dada sua natureza:

As grandes instituições e organizações geralmente temem a união dos irmãos, dos participantes dos grupos, percebendo-os como uma força que pode voltar contra elas. A fantasia inconsciente institucional é a de que a união dos participantes do grupo pode destruir o instituído. Isso é freqüente em instituições totais e constituídas de autoridades déspotas e verticais. Assim, as relações fraternas grupais tornam-se concorrentes dessas fantasias institucionais, autoritárias e centralizadoras. Nas organizações geridas pelo autoritarismo é impossível o trabalho de escuta e de diálogo (Pereira, 2004).

Vejamos outros dados sobre a rotina diária em Loppiano, de acordo com Urquhart (2002, p.62), ainda ilustrativos do funcionamento das instituições totais e de seus efeitos de modelagem subjetiva:

Geralmente o despertar era às 6 horas e $30 \mathrm{~min}$. ou às 7 horas. As atividades do dia começavam às 7 horas e 30 minutos. com uma meditação, que sempre consistia em uma "experiência de grupo"comentada por um líder. Ele lia o evangelho da missa do dia e fazia um breve comentário. Dos cem ou mais presentes - o primeiro e o segundo ano do curso - ele escolhia aleatoriamente aqueles que iriam participar de uma "experiência" inspirada na leitura. Esta era uma situação controlada, na qual a co-participação na "experiência" podia ser corrigida e as nossas vidas passadas redefinidas em termos da doutrina do movimento, conhecido método de reforma do pensamento. ...O medo de ser criticado nessas reuniões fazia parte daquele sentimento de ansiedade criado em Loppiano das mais diversas formas. Depois da meditação, havia meia hora para o café da manhã e, logo depois, trabalho das 8h30min até 13 horas. Havia então o tradicional almoço italiano que durava até 15 horas, e, depois novamente, trabalho até 19h30min ou 20 horas, que era hora da missa. Depois da missa tínhamos o jantar, e freqüentemente havia novamente reunião no salão principal, de 21 até meia-noite ou mais tarde. Muito ocasionalmente havia um show em que nós mesmos nos apresentávamos ou alguma sessão de cinema.... Nós trabalhávamos aos sábados pela manhã e à tarde ficávamos livres para a limpeza da casa ou para as atividades de grupo em nossas pequenas comunidades (mas não para ir à cidade, o que seria realmente impensável). (Urquhart, 2002, p.62).

Outras estratégias do Focolare, segundo Urquhart: para cumprir eficientemente sua tarefa, o movimento sistematiza, por meio de palestras redigidas previamente, um conteúdo simples, claro e compacto que deveria ser transmitido, difundido e inculcado em todas as instituições do movimento. Com o objetivo de dar ao curso realizado em Loppiano durante dois anos um certo status legal para a hierarquia eclesiástica, também havia aulas ministradas duas manhãs por semana. Havia professores focolarinos formados em Bíblia, História da Salvação e inclusive em Filosofia e Teologia:

Embora esses professores fossem realmente bons e bem preparados, eram pouco considerados pelos estudantes, que os tinham em conta de "intelectuais" e, por causa disso, eram desprezados. Muitos estudantes, freqüentemente os favoritos das autoridades, dormiam abertamente durante as aulas. Esta atitude era tacitamente aprovada por nossos superiores. No final do ano éramos submetidos a exames orais ridiculamente simples, exames para os quais ninguém estudava e, apesar disso, todo mundo passava (Urquhart, 2002, p.63). 
É possível perceber que o processo formativo dá pouco ou nenhum destaque para a dimensão intelectual. A persuasão ali não parece passar pelo aspecto racional, que é desligado tanto quanto possível. Parece ser a tecnologia microfísica (Foucault, 1999) que atua na aldeia de Loppiano. Ao atentarmos para as práticas institucionais que ali são implementadas, podemos verificar toda uma "arte das relações de poder" (Foucault, 1999, p.245) que é aprendida ao mesmo tempo em que se é submetido a ela, sem maiores teorizações. O corpo mesmo parece ser o objeto da formação/conversão/modelagem ao formato do movimento. Seria esse um modo mais fácil de garantir que o tratamento recebido pelos noviços focolares fosse fidedignamente transmitido aos futuros adeptos do movimento?

Loppiano também funcionava como uma vitrine do movimento e recebia centenas de visitantes todos os domingos. Aí os noviços tinham que trabalhar de modo extenuante para receber, alimentar, entreter e festejar os visitantes, de maneira que saíssem dali "convertidos":

A primeira tarefa das manhãs de domingo, depois da meditação, era a leitura em voz alta das tarefas do dia. Alguns de nós ficavam encarregados de supervisionar a circulação de veículos; outros iam ajudar nas cozinhas; os membros da turma de residentes e aqueles que eram conhecidos por terem boas "experiências" para contar seriam encarregados do show. A tarefa que mais nos apavorava era a de acompanhar os grupos. Éramos escalados para entrar em contato com um determinado carro e passar o dia inteiro com os ocupantes. Por mais exaustos e deprimidos que nos sentíssemos, era nosso dever nos misturar a eles, estabelecendo contatos pessoais com todos eles, e de, à custa de muita alegria e delicadeza, convencê-los de que aquilo era a Utopia (Urquhart, 2002, p.64)

Todos os noviços tinham que se demonstrar prestativos e diligentes, numa animação artificial, apresentando um vasto espetáculo que transformava Loppiano, por um dia, em uma espécie de disneylândia espiritual. Trata-se aí de uma muito bem desempenhada apresentação institucional, devidamente mapeada por Goffman (1987, p.90).

O relato sobre a experiência no Focolare nos apresenta, ainda, outros aspectos do funcionamento institucional em que se destacam de forma clara os procedimentos de modelagem subjetiva por acréscimo. Não parece estranho, diz o autor, que esse microcosmo institucional totalitário acabe produzindo seus próprios códigos de conduta, a partir de uma escala de valores original para medir o desempenho dos noviços em preparação. Além do culto à personalidade de Chiara Lubich, em Loppiano também havia o culto ao líder local da comunidade, sempre cercado de jovens que voejam em torno dele, uma "corte de favoritos" esperando para"colher as pérolas de sua sabedoria":

\begin{abstract}
Havia focolarini que se escondiam no guarda-roupa do líder, ou debaixo da sua cama, e que se levantavam de repente no meio da noite para obter um favor. Outros ficavam rondando dias e dias em torno da sua antecâmara, fora do seu escritório, um lugar lendário para nós: eles pediam uma entrevista, ou, outras vezes, simplesmente ficavam olhando para ele com expressão de cachorro submisso quando ele entrava ou saía. Ele mesmo alimentava a crença insidiosa de que, se você estivesse "em unidade", ele notaria sua presença, do contrário, ele não o veria. Este era outro mito que criava tensões artificiais e ansiedades em nós. Como acontece com muitos dos mistérios fictícios criados dentro dos novos movimentos, é impossível saber o que fazer para ser visto e para ter sua presença "notada" (Urquhart, 2002, p.64).
\end{abstract}

É evidente como certos rituais de tiranização subjetiva dos internos parece funcionar de modo a implementar e reforçar anseios narcísicos do tipo "culto das personalidades" (Lasch, 1983), fator que tende a propiciar a submissão cega aos ditames do superior/mestre.

Outro aspecto das práticas institucionais empreendidas nesse contexto, com o mesmo fim, consiste na submissão do internado a um outro detentor de um poder absoluto. A responsabilidade principal do líder/formador é verificar e atestar a autêntica vocação dos noviços-candidatos, selecionando, por meio da observação, os indivíduos considerados aptos para pertencerem ao grupo e dispensando os outros. Aparentemente considera-se que a autêntica vocação se manifesta em sinais, motivações válidas para a admissão. O discernimento vocacional realizado pelos dirigentes parece baseado, sobretudo, na observação dos comportamentos. Como nas instituições totais, o candidato é enclausurado para melhor ser observado, como um 
objeto expropriado de sua singularidade, que, quando emerge, tende a ser tomada como perturbação. A vocação pode ser considerada como portadora de uma essência passível de verificação fenomenológica, isso resultava em uma situação em que o futuro do internado era decidido unilateralmente pelos dirigentes a partir de pretensos dados objetivos (Urquhart, 2002).

No relato desse autor há, ainda, outro aspecto do processo de modelagem subjetiva que merece ser sublinhado: os líderes, "canais da unidade", exigiam dos noviços um esvaziamento total, uma aniquilação completa da vontade, para estarem em "unidade" com eles e com o movimento Focolare.

No interior desse mundo irreal, com suas angústias artificiais, nossas faculdades mentais e nosso senso crítico diminuíam. Ao mesmo tempo, a demanda por uma obediência total e irracional crescia.... Diante de nosso superior, nós temos que ficar vazios, que sermos nada, uma simples criatura sem a menor capacidade de questionamento: temos que aceitar qualquer capricho dele. ... A "unidade" requerida não é apenas a obediência cega no plano externo, é também um assentimento da mente, chamado de "unidade da mente" ou "unidade do pensamento". "Unidade" não era absolutamente o conceito igualitário que eu imaginara, mas uma reinvenção da autoridade absoluta e da hierarquia rígida (Urquhart, 2002, p.66).

Esse conceito de unidade e de comunidade pregado pelo movimento Focolare parece não deixar espaço algum para uma vida autônoma nem para pesquisas pessoais. Não é preciso buscar nada quando todas as respostas já foram dadas pelo grupo. A única coisa a fazer é interiorizar e ruminar constantemente os ensinamentos do mestre do movimento. A submissão total ao líder local unia o noviço automaticamente ao fundador do grupo. Parece inevitável vermos aí um rito de modelagem subjetiva de caráter radical. A"Unidade" em questão não se refere ao Um da singularidade, que se conta como mais um, mas ao Um da unificação, que supõe o apagar-se em benefício do outro, líder ou grupo, que culmina num tipo de identificação global que está na base da submissão massa-líder proposta por Freud (1921, 1925), a que já nos referimos anteriormente, e da qual aparece como corolário necessário: a atitude fanática.

Tal característica das instituições totais e de suas

348 conseqüências também já havia sido identificada por
Goffman (1987, p.59): nelas os indivíduos tendem a adotar comportamentos altamente obsequiosos para com a autoridade. São as estratégias adaptativas nomeadas como "colonização", na qual o indivíduo tende a adotar a vida no estabelecimento como se fosse a de seu lar; e como "conversão", tática em que o internado procura aceitar a interpretação oficial da equipe dirigente, buscando representar o papel do internado perfeito, disciplinado, moralista, sempre à disposição da autoridade.

Nessas circunstâncias o colonizado tende a tornar-se o agente mais feroz da colonização. A propósito, Urquhart também nos fala sobre sua percepção da equipe formadora, afirmando que seu trabalho "formativo" era executado com convicção, apesar dos altos custos emocionais e com grande desgaste pessoal para os membros da equipe dirigente:

Esta teoria da unidade era particularmente apavorante em Loppiano, porque muitas das pessoas que ali tinham autoridade haviam sido mandadas para lá porque tinham problemas; eu agora sei que muitas delas sofriam de estresse ou de depressão profunda - talvez outras tivessem apenas dificuldades com o próprio movimento. Para eles, Loppiano era uma espécie de prisão aberta onde seus problemas podiam ser controlados. É claro que alguns deles apresentavam comportamentos muito estranhos (Urquhart, 2002, p.67).

Afirma ainda que era angustiante ficarem submetidos à autoridade absoluta do líder, que podia ser uma pessoa problemática e arbitrária, mas "a idéia de apresentar queixa a uma autoridade superior era totalmente inadmissível no quadro de referências do Focolare" (Urquhart, 2002, p.67). Psicologização ou sociologização das contradições sociais e das conflitivas relações de poder existentes no estabelecimento parece ser mais um dos modos de lidar com possíveis formas de contestação ou resistência.

Éramos submetidos a uma chantagem espiritual que era a seguinte: se tivéssemos problemas, os únicos culpados éramos nós mesmos. Mas, além disso, havia uma pressão muito maior, que podia ser formulada assim: por mais infelizes que nos sentíssemos, não havia nenhum meio de escapar. Era impossível sair dali. Como trabalhávamos simplesmente para garantir nossa manutenção, não tínhamos acesso ao dinheiro. Muitos de nós vinham de outros continentes, ficando 
assim inteiramente à mercê do movimento. Nossas forças de resistência estavam tão enfraquecidas que, se quiséssemos sair dali, a simples perspectiva de ter de persuadir nossos superiores a nos deixar ir embora já era aterradora demais. ... Mas isso significaria uma ruptura total com o movimento e, naquele contexto, era impossível imaginar a vida fora de sua influência. Não havia, por conseguinte, nenhuma alternativa real: o caminho era a rendição total (Urquhart, 2002, p.67).

A partir das conclusões possíveis de nossa análise do Focolare, poderíamos perguntar até que ponto ele não pode ser considerado expressão das características dos novos movimentos religiosos leigos neofundamentalistas, na medida em que, como esses, ele comumente utiliza uma pedagogia eminentemente tradicional, caracterizada pela ênfase na transmissão autoritária de conhecimentos do mestre para o discípulo. O mestre/líder ocupa o centro da atividade pedagógica/ formativa. O relacionamento entre o mestre e o aprendiz é marcado pelo autoritarismo do primeiro, detentor do saber, da competência e do poder. O bom discípulo é aquele que assimila totalmente o conteúdo e adota os comportamentos, idéias, crenças, valores e discursos prescritos. Autoritarismo social, disciplina rígida, ordem e submissão, imposição de idéias e conceitos, valorização da hierarquia e da tradição parecem caracterizar esses grupos, além dos outros rituais comuns às instituições totais.

Sua técnica predominante é a da inculcação autocrática, visando à fixação da doutrina do líder fundador. Sua pedagogia é tradicional, enfatizando a obediência à autoridade e não estimulando o senso crítico nem a criatividade. Aristocrática, essa tendência pedagógica se pauta por valores e práticas autoritárias, visando à adaptação do indivíduo à sociedade, num processo de reprodução das relações sociais hegemônicas de dominação-subordinação. Não há acompanhamento pessoal baseado num diálogo entre iguais, conforme o preconizado nas práticas pedagógicas dialéticas baseadas na persuasão, no consenso e realizadas a partir da produção coletiva e da criação comunitária. A máquina funciona por si mesma: sua tecnologia produz efeitos automaticamente, basta estar inserido e encerrado nela. Viver no estabelecimento é formativo por si só, dados seus mecanismos rigidamente instituídos, sua manipulação dos temores individuais e seus efeitos microfísicos.
Apesar dessa prática pedagógica autoritária, o discurso institucional tende a responsabilizar o indivíduo pelo seu sucesso ou fracasso no processo formativo, aproximando-se da pedagogia renovada, baseada no pensamento liberal, que coloca a ênfase no desenvolvimento da personalidade do aprendiz. Inversamente ao modelo das pedagogias dialéticas, o discípulo, e não o coletivo, torna-se o centro da prática pedagógica. Nesse contexto o processo de psicologização do sujeito pode ser entendido como uma estratégia mistificadora que se superpõe às relações de poder, ocultando-as por meio de um discurso lacunar e deslocando-as para a interioridade individual: parece clara uma particularização de fenômenos que são originalmente, sobretudo, de ordem social e coletiva.

\section{Análise dos efeitos éticos da tecnologia totalitária de produção de subjetividade}

Qual é o efeito de uma experiência como essa em termos éticos? Que tipo de sujeito se produz a partir dos operadores institucionais utilizados pelos movimentos religiosos (Ferreira et al. 2005; Galindo, 1994; Lubich, 2003; Martelli, 1995; Urquhart, 2002) que estamos estudando? Quais são seus efeitos em termos de produção de subjetividade?

Operando basicamente por subtração (da liberdade, do tempo, da autonomia, da capacidade de reflexão, de escolha e de decisão, eliminando comportamentos indesejáveis e instaurando novos mais adequados, etc.), por meio da identificação baseada tanto no eu quanto nos ideais, mas, sobretudo, por meio de acréscimos de imaginário (doutrina do movimento, idéias, crenças, conceitos, representações, modos de se ver e olhar para a realidade, etc.), a tecnologia empregada em Loppiano pode produzir uma subjetividade serializada de matiz fortemente fanático. Não há espaço para a individualidade, para a iniciativa criadora, para a singularidade. Como o psiquismo pode reagir a essa modelagem institucional? Isso tem efeito permanente? Será que essa "criatura institucionalizada" pode se desconfigurar e buscar rumos diferentes e divergentes da programação imposta?

A resposta a tais questões, fundamentais para pesarmos certos impasses da subjetividade contemporânea, só pode ser ensaiada a partir de dados mais 
amplos do que os que temos no momento. Porém ao menos um aspecto parece evidente: há indivíduos que suportam e se adaptam a essa modelagem, e tão bem, que são eles que reproduzem e, portanto, perpetuam a instituição; mas há outros aos quais essa conjuntura coloca em situação agonística. No caso dos últimos, não estando dadas na estrutura institucional quaisquer outras possibilidades alternativas, só Ihes resta a saída da instituição. É o caso do sujeito de cuja experiência se ocupa nossa análise.

\section{0 processo de entrada, permanência e desligamento do movimento Focolare}

Se, conforme acabamos de constatar, estamos diante de uma tendência eclesial de viés fundamentalista radical que se mostra contrária ao valor do diálogo, da participação, da deliberação coletiva em busca de consenso; rejeita toda forma democrática de poder e gerenciamento político; tende a manipular predominantemente a dimensão emocional dos indivíduos e grupos em busca de restaurar um passado mítico; então como explicar que alguém deseje entrar para um movimento tão altamente fanatizante e permanecer nele? As possíveis razões da entrada e da permanência podem ser analisadas a partir do mesmo conjunto de dados. Encontramos em Libânio (1984) uma primeira tentativa de explicação:

Outra força e recurso dessa posição tradicionalista consiste em apresentar diante dos problemas teóricos e práticos respostas simples, lapidares, firmes, assim questões complexas são simplificadas ao extremo, dando ao fiel a tranqüilidade de ter resolvido e de possuir, portanto, solução clara e distinta. ... Em momentos de crise e perplexidade, em que vivemos, tal posição desperta certo fascínio sobretudo sobre personalidades angustiadas, inseguras. Traz alívio, pelo menos momentâneo, para a angústia da dúvida e do questionamento. Freqüentemente as soluções não passam de evasão, de ilusão, por desconhecerem a gravidade e complexidade da problemática. Quem sabe que parte de sucesso entre setores jovens de posições tão radicais conservadoras tenha a ver com uma etapa da evolução de certas personalidades inseguras, de horizonte ainda curto intelectualmente, em momentos de crise, de perplexidade, de dúvida? Assim as psicologias frágeis deixam-se atrair por posições claras, firmes, simplis- tas. Por outro lado, no meio dos tradicionalistas surgem personalidades fortes de liderança que arrastam após si pessoas mais vulneráveis psiquicamente. (idem, p.127).

Segundo esse autor, o momento histórico posterior ao Concílio Vaticano Il mergulhou os católicos numa certa anomia, tal a constância e velocidade das transformações. Isso teria suscitado um desejo de ordenamento, de pontos de referência que dessem segurança. Libânio (1984) considera que situações de crise institucional são propícias para a emergência de posturas submissas e autoritárias, nas quais um mesmo indivíduo pode assumir atitudes de "senhor" ou de "súdito", conforme a conveniência:

Mais facilmente, nestes momentos as psicologias fracas, abaladas em sua segurança, desejam neuroticamente um apoio. E como reflexo do caráter oposto, outras personalidades se sentem provocadas em seu instinto autoritário. Na sua estrutura profunda, seja o impulso de buscar apoio em outro, de submeter-se, como o de autoritarismo, são semelhantes. Ambos revelam uma fuga à liberdade e à individualidade, estabelecendo uma relação de dependência simbiótica com um outro objeto. No caso, o autoritário se identifica com o poder. O submisso foge à liberdade e à individualidade. Os dois pólos se casam bem, alimentando-se mutuamente. (Libânio, 1984, p.157).

Quanto aos motivos da permanência, Urquhart (2002, p.416) explica seu caso, depois de nove anos de pertença ao Focolare:

Os anos que passei no Focolare foram provavelmente os mais infelizes e os mais improdutivos de toda minha vida. Mas eles nos ensinavam que o sofrimento é essencial para o nosso estilo de vida; "Jesus abandonado" era a chave para a unidade, por isso nós tínhamos que sofrer. Esta foi a razão pela qual tive de suportar um estado de tormenta interior durante tantos anos. A minha decisão de sair do movimento não foi uma decisão pensada e consciente. A "Santa Jornada" do Focolare é uma jornada não de autodescoberta, mas de autodestruição e esquecimento de si próprio. Como ficamos alienados de nossas próprias emoções deliberadamente suprimidas, qualquer decisão pessoal é simplesmente impossível. Além disso, todas as escolhas para os indivíduos são feitas pela comunidade "em unidade". 
Vemos que de certa forma ele acrescenta outros fatores institucionais aos do indivíduo. As razões da ordem estão na reafirmação da própria posição do indivíduo como sofredor a serviço de algo maior, alem dos efeitos do processo de institucionalização que chamamos rituais de mortificação do eu e de colonização subjetiva, que deixam os indivíduos sem capacidade de tomar decisões de caráter pessoal.

Além de Libânio (1984), outros pensadores têm formulado idéias na tentativa de responder a essa questão. Merecem destaque as considerações de Freud (1921, 1927 e 1932), as de Lasch (1983) e as de Lindholm (1993).

Em "O problema da Concepção Unitária do Universo", Freud (1932) analisa o que considera uma característica da vida psíquica humana: a exigência de resolução unitária de todos o problemas de nosso ser; essa tendência à totalização teria um caráter afetivo e, ao mesmo tempo, frágil por ser resultante da dificuldade de lidar com o desamparo, a incompletude e a indeterminação das situações da vida concreta. Em "Psicologia das Massas e Análise do Eu", Freud (1921), ao estudar os grupos do tipo massa, caracteriza-os como uma estrutura particular em que o líder assume na subjetividade dos indivíduos a função muito mais de um objeto ideal de consistência narcísica e imaginária, do que de um suporte capaz de permitir ao indivíduo orientar-se na direção dos ideais da cultura. Tratar-se-ia de conjunturas nas quais para os indivíduos não estaria sendo possível marcar a distância entre o ego atual e o ego ideal; nesses casos, o líder como ego ideal seria requisitado para fazer as vezes do objeto de identificação, o que tende a implicar em identificações maciças do eu com o outro. Finalmente, em "O Futuro de uma Ilusão", Freud (1927) assinala que os homens podem responder diferentemente aos enigmas ante os quais se choca o desejo de saber e a tolerância ao desamparo. Alguns exigem respostas de teor absoluto e totalitário, outros toleram mais a dúvida e a indeterminação. Parece acenar com uma tentativa de diferenciar dois modos da consistência subjetiva, definidos segundo a consistência mais imaginária ou mais simbólica dessa relação do homem com o mundo, que determina suas formas de resposta aos enigmas com que este o interpela. Esses argumentos freudianos estão claramente na direção de indicar possíveis fatores da entrada e da permanência dos indivíduos nessas instituições.
Lasch (1983) foi um dos primeiros pesquisadores a abordar uma série de inflexões na subjetividade, partindo da hipótese de que transformações na sociedade contemporânea podem incidir na subjetividade dos indivíduos de modo a influenciar as modalidades das relações objetais. Propôs o conceito de "Cultura do Narcisismo" para designar o caráter regressivo dessas transformações. Em uma de suas teses principais afirma que a maneira como estão organizadas as relações sociais no modo de produção capitalista das sociedades de capitalismo desenvolvido, das quais a sociedade americana seria um dos protótipos, enfraquece de tal modo as relações dos indivíduos com o campo do simbólico que se chega à constituição de egos enfraquecidos, que se tornariam propensos à busca de experiências de êxtase e aos vínculos carismáticos.

Finalmente, Lindholm (1993) agrupa uma série bastante ampla de fenômenos sob o título de carisma. Considerando a mesma conjuntura geral de desamparo material e subjetivo, que está na base da "Cultura do Narcisismo", pensa que nessas circunstâncias alguns indivíduos tenderão a procurar outros com quem possam se identificar, buscando experimentar uma poderosa sensação de perda dos limites do eu, se essa não oferecer perigo de total desintegração; tomando o outro como apêndice constitutivo da própria unidade do eu, estabelecem com ele relações de extrema dependência, ao mesmo tempo em que experimentam sensações de absoluta completude (sentimento oceânico). Para esses indivíduos, o outro em questão seria sempre um representante direto do primeiro objeto da fase do desenvolvimento da personalidade correspondente ao narcisismo, em que se sobressai a exigência de completude. Eles se encontrariam em um impasse quanto ao engajamento pleno no simbólico, que thes propiciaria um tipo de completude pela via dos ideais, passível de permitir uma relação com a transcendência fora das vias do tipo fanático. Para esse autor tais personalidades também têm seu aparecimento em conjunturas em que os padrões externos estão corroídos e as figuras de autoridade são consideradas ilegítimas. É aqui que os líderes carismáticos se apresentam como possibilidade de "superegos substitutos", que podem, e estão autorizados a, externalizar a agressão. "Quando a autocracia interna do superego desaparece, ela renasce externamente ... torna-se o poder coercitivo do sacerdote, do príncipe, do feiticeiro e do grupo" (Lindholm, 1993, p.105). 
Podemos perceber que o conjunto de explicações levantado nos diferentes autores está muito mais interessado em responder às questões sobre possíveis fatores da entrada e permanência, enfatizando o lado dos liderados. E quanto aos líderes, Libânio (1984) fala em personalidades frágeis e fortes, entretanto o conceito de personalidade forte é bastante problemático, uma vez que parece, tanto o líder quanto os liderados, tratar-se de indivíduos que têm demandas da mesma natureza; trata-se nos dois casos da mesma forma de identificação, embora uns o façam utilizando o poder e outros o sofram como objeto de dominação. O que parece mais difícil de ser compreendido são os possíveis fatores dessa identificação diferencial. Ensaiamos uma pequena explicação: há uma diferença básica naqueles que ocupam o lugar de líder - a liberação de um componente perverso da personalidade permitindo que eles gozem por bancarem o grande Outro para o outro; sua vivência de completude poderia vir então dessa identificação direta com Deus. Vale a pena esclarecer que dizemos liberação porque é necessário considerar a possibilidade do gozo perverso como acessível à conjuntura psíquica definida como personalidades narcísicas, senão como explicar que, dependendo das circunstâncias, o indivíduo possa passar de liderado a líder? Por outro lado é importante esclarecer que não se trata necessariamente de subjetividades "perversas" (formadas por renegação do significante do Nome do Pai (Dor, 1991, p.93), em que a função pai estaria renegada; trata-se de subjetividades "neuróticas", nas quais a função pai está admitida (por recalcamento), só que por meio de uma identificação massiva, portanto, de modo diferente daquele da construção de uma identidade (conforme definição anteriormente proposta para identificação e identidade).

E quanto às possíveis razões da saída: por que o indivíduo deixaria o grupo ou movimento religioso fundamentalista no qual ingressou? Uma primeira explicação poderia residir em que tais grupos, dada a sua consistência e funcionamento, tendem a se recusar ao diálogo com a modernidade, conduzindo seus participantes a se fixarem na postura fideísta ingênua em que estão ancorados (Brighenti, 2001, p.20). Ou seja, "escolhem-se os atalhos do coração, do testemunho, da vivência, do emocional para chegar à Revelação,

352 saltando a longa caminhada da razão, com medo de perderem-se nos labirintos da crítica" (Libânio, 1984, p.152).

Quanto a essa questão vale a pena analisar alguns elementos do percurso de Urquhart (2002): terminado o período preparatório em Loppiano, foi enviado para Liverpool para abrir uma nova comunidade masculina. Foi trabalhar como professor e essa inserção "no mundo" foi aos poucos Ihe dando conta das transformações da realidade social da qual esteve alijado pelo movimento. Havia um vácuo em seus conhecimentos quanto aos filmes, livros, teatro para preencher. Ele começou a desenvolver um trabalho com encenações teatrais, dando início a uma fase de iniciativa, criatividade e independência que não eram bem vistas pelo grupo. Mas havia também um segredo permanentemente atormentador: sua orientação homossexual:

Desde os meus 12 anos, mais ou menos, eu tinha consciência de que sentia uma certa atração pelos outros garotos de minha idade, ou mais velhos. Nas escolas católicas não se falava desse assunto naquela época, talvez nem mesmo hoje, e desta maneira eu me informava da melhor maneira possível, folheando livros de Freud nas bibliotecas. Durante muitos anos, mesmo depois de ter saído do movimento, considerei essas"tendências homossexuais" como tentação ou vício, muito mais do que como parte de minha própria estrutura psicológica. Quando terminou minha adolescência, comecei a tomar consciência de que aquilo não era simplesmente uma "fase" que passaria com o tempo, mas meu catolicismo sincero me forneceu meios de engavetar o problema e tratei de sublimar totalmente todos os impulsos sexuais. Quando descobri o Focolare eu já tinha ficado virtualmente assexuado aos 17 anos de idade (Urquhart, 2002, p.418).

Sem dúvida, no caso de Urquhart (2002), a perspectiva do celibato podia soar bastante atraente por permitir protelar indefinidamente qualquer espécie de opção sexual, adiando para sempre qualquer experiência concreta, mesmo tendo uma consciência permanente de sua orientação específica. A tensão entre seus desejos eróticos (socialmente desaprovados e condenados pela religião) e a doutrinação constante quanto à pureza absoluta do"ideal"Focolare (um projeto de vida institucional altamente promissor) foi resolvida temporariamente em favor da segunda alternativa. Pode-se dizer que o movimento Focolare the econo- 
mizava uma neurose pessoal, oferecendo-Ihe uma possibilidade de repressão segura e significativa.

Conforme o tempo passava e seu envolvimento institucional com o Focolare aumentava, também aumentava sua necessidade de confessar seu segredo aos superiores: não esconder nada deles significava estar "em unidade", já que os líderes eram o "foco da unidade". Esse impulso de auto-revelação conflitava com o temor da expulsão do movimento e a conseqüente impossibilidade de tornar-se um focolarino com seus votos e pertença permanente ao grupo. Depois de muita incerteza e hesitação, Urquhart (2002) confiou sua história ao seu superior:

Sua reação foi para mim uma surpresa. Meus sentimentos não tinham nada de errado em si mesmos, enquanto eu não fizesse nada. ... O único conselho que recebi foi a resposta mágica do Focolare para todos os problemas - "amar a Jesus abandonado". Isto significava que no meu caso - como, estou certo disto, em muitos outros - o ponto fundamental nunca era enfrentado. "Jesus abandonado" era uma espécie de tapete cósmico para debaixo do qual eram jogados todos os assuntos desagradáveis e mais dolorosos. Este conceito encorajava a "cultura do segredo" do Focolare. Nós éramos proibidos até mesmo de falar sobre nossas dúvidas e dificuldades com os amigos dentro do movimento. Não devíamos compartilhar com os outros nossas "misérias". De acordo com a mentalidade do Focolare, um problema compartilhado era um problema dobrado (Urquhart, 2002, p.418)

Na temporada em Loppiano, depois de esforços heróicos, ele conseguiu se dominar: "Graças a uma imensa força de vontade consegui finalmente dominar minha batalha interior e ceder à euforia geral" (Urquhart, 2002, p.420). Já durante o segundo ano em Liverpool, ele passou por uma experiência de ruptura radical na qual o reprimido irrompeu de modo violento e irracional, numa autêntica microcrise psicológica - uma atuação de caráter tipicamente homossexual:

Numa reação desesperada aos anos de esforços para esquecer e reprimir, eu me vi no cenário de 'Morte em Veneza', sem jamais ter ouvido falar nem do filme de Visconti nem do romance de Mann. Num impulso eu faltei ao colégio e fiquei procurando um misterioso estranho escolhido ao acaso ao redor do centro de Liverpool. Quando caiu o crepúsculo, eu recuperei abruptamente os sentidos, como se estivesse acordando de um sonho. Não consegui achar nenhuma explicação para meu comportamento e tive medo de estar perdendo a razão. ... O que este incidente indicava sem dúvida era uma crise pessoal profunda que devia ser resolvida (Urquhart, 2002).

Esses abalos iniciais foram se aprofundando. Contudo, Urquhart foi estimulado a fazer os votos de castidade, pobreza e obediência. Ele foi transferido para Londres e teve que deixar um trabalho muito gratificante em Liverpool. Tornou-se editor da Revista New City e rompeu com a proibição do movimento de ler jornais e revistas (Urquhart, 2002, p.423). Descobriu que a homossexualidade havia deixado de ser um crime, passando a ser tema corrente e inclusive tratado de modo positivo por diversas publicações. Essas novas influências precipitaram a eclosão de uma crise pessoal intensa:

Comecei a sofrer seriamente de insônia, problema que nunca experimentara em toda minha vida. Esperava que isso passasse, mas a insônia continuou por muitos meses. Foi então que apareceu um outro sintoma: ataques de pânico que se manifestavam toda vez que eu ficava sentado durante períodos muito longos. Nada surpreendente, isto ocorria principalmente durante as reuniões do movimento. Eu tinha que lutar contra um desejo poderoso de sair correndo do quarto ou da sala de reuniões e continuar correndo pela rua. Durante nosso retiro semestral em Roma eu não pude sequer acompanhar as palestras de Chiara: eu suava e me contorcia, procurando dominar o impulso de sair dali. Ao mesmo tempo, o problema de minha sexualidade reprimida por tanto tempo já não podia ser ignorado. Eu agora sentia que precisava entender a verdadeira natureza de meus sentimentos. Eu sabia que os sintomas estranhos e angustiantes que me afligiam só iriam encontrar resposta fora da comunidade Focolare (Urquhart, 2002, p.423).

Urquhart iniciou seu processo de desligamento do movimento Focolare e descobriu que o grupo iria fazer de tudo para dificultar sua saída. Primeiro Ihe ofereceram ajuda, recomendando um tratamento psiquiátrico com um médico do movimento que além de psicoterapia e de remédio, recomendou-Ihe o casamento: "um poderoso antídoto contra as tendências homossexuais, principalmente por causa dos filhos" (Urquhart, 2002, p.427). 
O movimento autorizou-o, mesmo que a contragosto e apenas em caráter temporário, a viver fora da comunidade. Sua família aceitou sua decisão com rapidez e Urquhart foi viver em um apartamento com sua irmã. Mas a liberdade tem preço:"os primeiros problemas que encontrei foram de ordem financeira" (Urquhart, 2002, p.429). O movimento havia ficado com todos os honorários que ele havia recebido durante seis anos de voto de pobreza e não o ajudou a recomeçar sua vida "no mundo". "Sem recursos, eu saí da comunidade com muito menos, em termos de roupas e posses, do que quando entrei" (Urquhart, 2002, p.431). A liberdade imediatamente produziu efeitos saudáveis:

Eu tinha dado a mim mesmo um prazo de seis meses para negociar minha libertação do Focolare, e este prazo foi realmente um período de pesadelos, de luta contra a resistência do movimento. E ainda por cima eu tinha de enfrentar meus próprios problemas de saúde. Mas quando entrei no meu novo apartamento, tudo passou. Aconteceu então uma coisa extraordinária. Os sintomas de pânico e de angústia que me perseguiam há mais de um ano literalmente desapareceram da noite para o dia. E estes sintomas foram substituídos por uma emoção muito simples, quase banal, uma emoção que surgiu com a força de uma revelação. Pela primeira vez em seis anos, desde que entrara para a comunidade Focolare, eu experimentava, não de forma sobrenatural ou divina, mas de forma simples e humana, uma sensação de felicidade natural - uma emoção que, de acordo com a doutrina do Focolare, simplesmente não existe (Urquhart, 2002, p.431).

Reconquistando sua independência, logo Urquhart foi descobrir o mundo, recuperar seu atraso cultural, estendendo seu círculo de amizades mais além das imposições do movimento. Conforme ele se afastava e seus laços se afrouxavam com o grupo, mais o movimento o procurava e buscava enquadrá-lo, tentando manter domínio sobre Urquhart (2002, p.434). Ele resistia, embora o assédio e a pressão fossem fortes. Não querendo abandonar o movimento de todo, Urquhart pensava, ingenuamente, em manter um contato mais livre, sem o peso das estruturas do Focolare. Mas isso seria impossível.

Mesmo muitos anos depois, quando, para falar claramente, a possibilidade deste controle já não existia mais, eles continuaram a me ver como um elemento em sua estrutura de poder. Depois que descobriram que eu não cederia às pressões, o assédio terminou abruptamente. Eu fui relegado à categoria daqueles que estão identificados nos arquivos do Focolare com um " $M$ " - os mortos (Urquhart, 2002, p.437).

Parece necessário um grande esforço para superar os princípios integristas e explicitamente religiosos do movimento que foram inculcados e que se sedimentaram na vida pessoal do antigo adepto. A doutrinação pode ter efeitos colaterais prolongados, tais como a necessidade de falar freqüentemente do tempo vivido no movimento "para tentar dar um sentido ao que não tem mais sentido, para externá-lo e colocá-lo em perspectiva" (Urquhart, 2002, p.438), pesadelos repetidos com a cena institucional (Urquhart, 2002, p.442). Os "axiomas obsessivos do Focolare" desvalorizavam a vida humana corrente: amigos, família, trabalho, relações pessoais. Reencontrar o significado de tudo isso leva tempo. Urquhart recupera aos poucos a autoconfiança, seguindo a carreira de diretor de cinema. Mas deixou também de praticar a religião católica por cerca de dez anos (Urquhart, 2002, p.439).

Quanto à sua sexualidade, ele continuava fortemente influenciado pelo movimento:"A opção que me fora apresentada pelo movimento e seus agentes era muito clara: eu poderia seguir minha natureza gaye levar uma vida de pecado, ou poderia me casar. Era muito simples" (Urquhart, 2002, p.439). Um ano depois de sair do movimento, ele se casou, mas isso não funcionou:

Eu não quero colocar a culpa de minhas ações na conta do movimento. Na realidade, eu e outros tivemos que pagar caro por elas, sete anos e dois filhos mais tarde, sob a forma de um divórcio confuso e amargo. ... Mas ao tomar decisões - ou ao não tomá-las - a única matéria-prima com que temos de lidar somos nós mesmos. E quando me casei, após nove anos cruciais de doutrinação, eu era aquilo em que o movimento me transformara (Urquhart, 2002, p.440).

Conta que, finalmente, deparou-se com o grupo "Quest, a organização dos gays católicos. Na amizade simples e na humildade que encontrei entre os membros dessa organização, eu descobri que Deus não é propriedade exclusiva de nenhum movimento" (Urquhart, 2002, p.442). Ele conclui seu relato com uma grande consciência, depois do seu longo percurso: "A 
rejeição daquilo que é humano é a maior heresia dos novos movimentos, pois é impossível ser cristão se antes de tudo a pessoa não for plenamente humana" (Urquhart, 2002, p.444).

Esse percurso de Urquhart tem suas particularidades, mas não deixa de incluir também o singular. Nele podemos ver um exemplo das dificuldades de se desfazer da modelagem subjetiva a que são submetidos os indivíduos nessas instituições. Esse desligamento só se tornou possível por meio de um processo que inclui momentos rápidos de crise e momentos lentos. Os momentos de crise são constituídos pelo transbordamento da angústia e o indivíduo se vê projetado em uma ação que é mais uma passagem ao ato do que qualquer decisão refletida (para Urquhart, essa passagem ao ato se deu no terreno da sexualidade e como abandono temporário da religião católica; para outros ela pode consistir na fuga ou simples abandono da instituição). Os momentos lentos constituem uma dimensão paulatina do processo de separação em que o indivíduo vai exercitando a reversão dos "axiomas obsessivos do Focolare" que desvalorizam a vida corrente: amigos, família, trabalho, relações pessoais (tais momentos lentos incluem certas recaídas como a necessidade de falar freqüentemente do tempo vivido na instituição e a recorrência de pesadelos com a cena institucional, aparentemente para dar sentido ao sem sentido vivido e conjurá-lo). O caso em questão nos mostra, ainda, que a saída da instituição não se confunde com a saída da configuração subjetiva que a adesão e a permanência nela produziram (Ferreira, Lauand \& Silva, 2005).

\section{Considerações Finais}

\section{O fanatismo religioso e suas relações com as características das instituições totais}

Foucault (1995, p.206) afirma que "as pessoas sabem aquilo que elas fazem; freqüentemente sabem por que fazem o que fazem; mas o que ignoram é o efeito produzido por aquilo que fazem"; por outro lado, a psicanálise há muito tempo nos ensina que nossas ações e palavras, quando se dirigem ao semelhante, como injunções, podem produzir efeitos bem mais amplos do que pretendíamos em nossas intenções iniciais. Trabalhamos com a hipótese de que os movimentos religiosos que estamos estudando desenvolvem práticas que podem ser pensadas como de caráter fanatizante. Com isso não pretendemos afirmar que necessariamente são constituídos por pessoas que possuem essa intenção deliberada. É possível que eles não consigam calcular os efeitos das práticas que implementam, nem visem conscientemente esse fim, entretanto esse parece ser um dos sentidos importantes de sua produção geral, de acordo com a literatura que temos compulsado. Assinalamos, de imediato, como principal característica da atitude fanática, a demanda radical de sentido de teor imaginário.

O fanatismo, independente do campo em que se manifeste (religioso, esportivo, político, ideológico, etc.), tende geralmente à fuga da realidade. O fanatismo religioso reduz o indivíduo fanático a um escravo diante do senhor: seu líder, uma divindade, uma causa suprema ou uma fé cega. Enraíza-se num gnosticismo exacerbado, se alimenta de um sistema de crenças absolutas e irracionais com o objetivo de servir um ser poderoso empenhado numa campanha contra o mal. O fanático se percebe investido de uma missão intransferível e inadiável de exorcizar o demônio das pessoas e coisas, ele combate contra as forças das trevas e busca salvar o mundo do caos e da perdição eterna. Sua causa suprema está acima de sua própria vida, da de sua família e inclusive das demais pessoas: ele é capaz de morrer ou matar por suas crenças.

Segundo Lima (2002), os sintomas do fanatismo incluem: orações, jejuns, privações, peregrinações, discursos monológicos e martírios, que podem levar ao sacrifício final do fanático, visando salvar o mundo das forças do mal que ele combate. O fanático não fala, fundamentalista, ele discursa para inculcar através da pregação religiosa sua crença ou doutrina, tornando a todos meros objetos de um desejo divinizado. Ele tem certeza e sua certeza é igual à verdade. O fanatismo religioso tem algumas características muito claras: um grupo ou um sujeito convencidos de que estão de posse da verdade com toda certeza, resistindo ao teste da realidade; querem impor a todos os demais de um modo despótico a sua "verdade", derivada de sua inspiração ou crença absoluta (buscam uma uniformização estereotipada da aparência, dos rituais, da linguagem, criando "chavões" e slogans próprios); a sua causa 
suprema é superior a tudo, inclusive à própria vida e a dos demais; o grupo se isola da coletividade, em busca de pureza, adotando um estilo de vida narcísico, fechado, sectário e uniformizante; com o tempo, o discurso do indivíduo ou do grupo torna-se repetitivo, bizarro, distanciando-se do bom senso na lógica comunicativa dialogal; finalmente, perdem o sentido de respeito pelos diferentes modos de existência humana, em nome de uma causa transcendente absoluta. O método de doutrinação fanática tem três etapas: inicialmente, busca seduzir pessoas para a "causa" do líder ou do grupo; depois realiza um processo de destruição da antiga personalidade, dissolvendo ligações familiares, profissionais e sociais; finalmente, procura construir uma nova personalidade, recriada de acordo com os moldes, modelos e normas do grupo. O fanatismo é perigoso, pois revela uma intolerância extrema para com os diferentes (Lima, 2002).

Ao longo desta análise já deixamos entrever um princípio de explicação do fenômeno do fanatismo. É preciso acrescentar que a atitude fanática perece enraizar-se em circunstâncias sócio-histórico-culturais agonísticas, em personalidades de um matiz também particular ("Cultura do Narcisismo" e avidez carismática). Em trabalho anterior arriscamos uma explicação para o fenômeno do fanatismo: contextos sócio-culturais agonísticos em termos do fechamento de perspectivas concretas e de ideais de desenvolvimento e mobilidade social; conjugados a personalidades narcísicas (regredidas do ponto de vista das relações interpessoais e objetais), que deixam tais indivíduos prisioneiros de demandas subjetivas radicais de sentido de teor imaginário. O preenchimento urgente e sem falhas dessa demanda é fator de estabilização psíquica para esses indivíduos. Porém, essa estabilização não deixa de ser claudicante, daí o desdobramento fanático, que é uma tentativa de conjurar, reiterando no próximo, por uma espécie de performance proselitista, a solução dos conflitos que no próprio fanático não acaba de se consolidar (Costa-Rosa, 1995).

A fanatização produz efeitos agonísticos de ritualização da existência, refletidos diretamente na subjetividade e no corpo dos indivíduos. Ela tem uma função congruente com a de certas práticas ritualísticas de outras instituições culturalmente mais arraigadas,

356 como o Candomblé e a Umbanda, entre nós, e uma série de rituais das sociedades chamadas primitivas. Os efeitos maiores dessas práticas culturalmente estabelecidas podem ser definidos como ritualização da existência, de alto teor de simbolização, dado o caráter de tradição cultural do sentido que veiculam para o cotidiano e a vida em geral, dos indivíduos adeptos. Quanto à fanatização propriamente dita, podemos defini-la como uma espécie de ritualização mal-sucedida, agonística, que se inscreve diretamente na vida subjetiva e no corpo dos indivíduos aderidos; esse efeito parece vir do baixo teor simbólico do sentido veiculado. Este não se inscreve mais em rituais compartilhados pela cultura mais ampla, mas na própria subjetividade, imprimindo-Ihe uma instabilidade mais drástica, o que acaba derivando na atitude fanática e proselitista como seu desdobramento necessário (não contingente). Nessa perspectiva, pode-se dizer que o fanatismo proselitista é um dispositivo agonístico disparado para defender a precária estabilização psíquica conseguida com a adesão mística.

Em suma, uma forma de estabilização sustentase culturalmente no coletivo, liberando o corpo e a subjetividade individuais, não há performance gnóstica (maniqueísmo) nem fanática (proselitismo). A outra, carente de sustentação cultural e coletiva, toma o corpo e a subjetividade individual como suportes, acentuando a atitude gnóstica já induzida pelo ideário das instituições e presente na própria subjetividade dos adeptos, produzindo uma performance fanática extrema (proselitismo compulsivo), como meio de manter a precária estabilização psíquica conseguida com a adesão à instituição.

Generalizando algumas de nossas hipóteses anteriores sobre o Focolare, podemos afirmar que os chamados novos movimentos religiosos presentes no atual contexto católico têm matizes nitidamente totalitários, pois se estruturam de acordo com o paradigma pré-moderno tridentino (Queiruga, 2003, Libânio, 2005, p.74). Estão alinhados com as forças hegemônicas eclesiais contemporâneas de matiz restauracionista, sendo alguns de seus traços mais marcantes: fanatismo, crescimento rápido e vigoroso, ausência de prestação de contas, segredo quanto a sua estrutura interna, silêncio total sobre a origem de seus recursos financeiros aparentemente ilimitados, método de recrutamento próprio de seitas, crenças esotéricas, perspectiva cultural limitada, repressiva e integrista, com posicionamentos 
morais conservadores e tradicionalistas. Triunfalistas, exercem um proselitismo agressivo. Mantêm segredo quanto às doutrinas arcanas que Ihes conferem o sentido de unidade e coesão interna.

O neofundamentalismo ultrapassa facilmente aquele mínimo de segurança normal, necessário, desviando-se pelas vias da patologia social, oferecendo a pessoas inseguras, ansiosas, neuróticas um apoio emocional, em vez de ajudá-las a uma decisão livre, pessoal e consciente. É enorme risco construir uma identidade sobre tipos neuróticos, seja pela via da submissão, seja pela via do autoritarismo: ambos inseguros, incapazes de assumirem em liberdade decisões fundamentais. Fogem, temem a liberdade. Esta é ameaça por demais grande para suportá-la com tranqüilidade. A autonomia madura revela-se na calma e paz em suportar e enfrentar o diferente, em atitude de diálogo. As situações autoritárias são patogênicas, enquanto que as democráticas, livres, dialogais são terapêuticas. Ora, quanto mais uma identidade for construída à base do diálogo, do consenso, tanto mais ela revelará o caráter sadio de seus construtores e permitirá que ela também possa ser vivida sadiamente pelos seus membros (Libânio, 1984, p.158).

Esses movimentos não parecem trazer respostas novas para problemas novos, ao contrário, buscam antigas fórmulas para problemas que não são os da contemporaneidade, parecem "vinho velho em velhos odres". Sob o prisma de tais movimentos, seria o cristianismo incompatível com a modernidade democrática, com a liberdade (como autonomia), com a igualdade (traduzida como reconhecimento das diferenças, da especificidade desejante, dos conflitos e contradições comuns, condições de possibilidade de crescimento) e com a fraternidade (enquanto solidariedade na ação conjunta dos projetos coletivos e no enfrentamento das vicissitudes na esteira do devir)? Ampliando nosso ponto de vista, pensamos que não, juntamente com diversos autores que propõem a superação do Paradigma Tridentino e a construção de uma nova realidade eclesial (Brighenti, 2001; Comblin, 1999, 2002; Libânio, 1984, 2000, 2003, 2005; Queiruga, 2001; Morano, 2003).

\section{Referências}

Aguiar, W. M. (2002). A pesquisa em Psicologia SócioHistórica. In A. M. B. Bock, M. G. Gonçalves \& O. Furtado (Orgs.), Psicologia Sócio-histórica: uma perspectiva crítica em psicologia (pp.129-140). São Paulo: Cortez.
Benelli, S. J. (2002). O internato escolar como instituição total: violência e subjetividade. Psicologia em Estudo, 7 (2), 19-29.

Benelli, S. J. (2003a). Dispositivos disciplinares produtores de subjetividade na instituição total. Psicologia em Estudo, 8 (2), 99-114.

Benelli, S. J. (2003b). Pescadores de homens: a produção da subjetividade no contexto institucional de um Seminário Católico. Dissertação de mestrado não-publicada, Faculdade de Ciências e Letras, Universidade Estadual Paulista, Assis.

Benelli, S. J., \& Costa-Rosa, A. (2002). A produção da subjetividade no contexto institucional de um Seminário católico. Estudos de Psicologia, Campinas, 19 (2), 37-58.

Benelli, S. J., \& Costa-Rosa, A. (2003a). Geografia do poder em Goffman: vigilância e resistência, dominação e produção de subjetividade no hospital psiquiátrico. Estudos de Psicologia, Campinas, 20 (2), 35-49.

Benelli, S. J., \& Costa-Rosa, A. (2003b). Estudo sobre a formação presbiteral num seminário católico. Estudos de Psicologia, Campinas, 20 (3), 99-123.

Blazquez, R. (1996). Las comunidades Neocatecumenales: discernimiento teologico. Bilbao: Desclee de Brouwer.

Brighenti, A. (2001). A Igreja do futuro e o futuro da Igreja: perspectivas para a evangelização na aurora do terceiro milênio. São Paulo: Paulus.

Comblin, J. (1999). O Cristianismo no limiar do terceiro milênio. In C. Caliman (Org.), A sedução do sagrado: o fenômeno religioso na virada do milênio (2a. ed., pp.143-160). Petrópolis: Vozes.

Comblin, J. (2002). O povo de Deus (2a. ed.). São Paulo: Paulus.

Costa-Rosa, A. (1995). Práticas de cura nas religiões e tratamento psíquico em saúde coletiva. Tese de doutorado em Psicologia não-publicada, Instituto de Psicologia, Universidade de São Paulo.

Cordonnier, G. (1995). Nascer de novo: os novos cristãos pelo caminho do catecumenado. Coimbra: Secretariado Nacional da Educação Cristã.

Dor, J (1991). Estrutura e perversões. Porto Alegre: Artes Médicas.

Fernandez, P (2004). La celebracion de la eucaristiaen el camino neocatecumenal. Revista Phase, 44 (260), 139-165.

Ferreira, D. F., Lauand, M., \& Silva, M. F. (2005). Opus Dei: os bastidores, história, análise, testemunhos. São Paulo: Verus.

Fondi, E., \& Zanzucchi, M. (2004). Um povo nascido do Evangelho: Chiarae os focolares. São Paulo: Paulus.

Foucault, M. (1999). Vigiar e punir: nascimento da prisão. Petrópolis: Vozes.

Foucault, M. (1995). O sujeito e o poder. In H. Dreyfus, P. Rabinow. Michel Foucault, uma trajetória filosófica: para além do estruturalismo e da hermenêutica (pp.231-249). Rio de Janeiro: Forense.

Freud, S. (1921). Psicologia de las massas e análisis del "YO" (Tomo III, pp.2563-2610). Madrid: Biblioteca Nueva. 
Freud, S. (1927). El Porvenir de Una Ilusion (Tomo III, pp.2961-2992). Madrid: Bibioteca Nueva.

Freud, S. (1932). Nuevas lecciones introductorias al Psicoanalisis. Leccion XXXV: El Problema de la Concepción del Universo (Weltanschauung) (Tomo III, pp.3191-3209). Madrid: Biblioteca Nueva.

Freud, S. (1925). La Negacion. (Tomo III, pp.2884-2886). Madrid: Biblioteca Nueva.

Galindo F. (1994). O fenômeno das seitas fundamentalistas. Petrópolis: Vozes.

Goffman, E. (1987). Manicômios, prisões e conventos. São Paulo: Perspectiva.

Goyomard, P. (1996). O gozo do trágico: Antígona, Lacan e o desejo do analista. Rio de Janeiro: Zahar.

Guattari, F., \& Rolnik, S. (1986). Micropolítica: cartografias do desejo. Petrópolis: Vozes.

Lacan, J. (1988). A agressividade em psicanálise (pp.104-126). In Escritos. Rio de Janeiro: Jorge Zahar.

Lacan, J. (1980). O mito individual do neurótico. Lisboa: SCARL.

Lasch, C. (1983). A cultura do narcisismo. Rio de Janeiro: Imago.

Le Tourneau, D. (1985). O opus dei. Lisboa: Rei dos Livros.

Libânio, J. B. (1984). A volta à grande disciplina (2a. ed.). São Paulo: Loyola.

Libânio, J. B. (2000). Igreja contemporânea. Encontro com a modernidade. São Paulo: Loyola.

Libânio, J. B. (2003). Olhando para o futuro: prospectivas teológicas e pastorais do Cristianismo na América Latina. São Paulo: Loyola.

Libânio, J. B. (2005). Impactos da realidade sociocultural e religiosa sobre a vida consagrada a partir da América Latina. Busca de respostas. Perspectiva Teológica, 37, 55-88.

Lima, R. (2002). O fanatismo religioso entre outros. Revista Espaço Acadêmico, 17. Acessado em julho 4, 2004 disponível em http://www.espaçoacademico.com.br/ 017/17ray.htm

Lindholm, C. (1993) Carisma. Rio de Janeiro: Zahar.

Lubich, C. (2003). Ideal e luz: pensamento, espiritualidade, mundo unido. São Paulo: Brasiliense.

Martelli, S. (1995). A religião na sociedade pós-moderna:entre secularização e dessecularização. São Paulo: Paulinas.
Morano, C. D. (2003). Crer depois de Freud. São Paulo: Loyola.

Oliveira, L. E. (1988). Jesus abandonado em Chiara Lubich: uma perspectiva para a inculturação do evangelho. Dissertação de mestrado em Teologia Sistemática não-publicada, Pontifícia Universidade Católica do Rio Grande do Sul, Porto Alegre.

Pasotti, E. (Org.). (1999). Ocaminho Neocatecumenal segundo Paulo VI e João Paulo II. São Paulo: Loyola.

Pereira, W. C. C. (2004). A formação religiosa em questão. Petrópolis: Vozes.

Perez, G. R. (1992). El Opus Dei: una explicacion. Madrid: Ediciones Railp.

Prada, A. V. (1989). O fundador do Opus Dei:Mons. Josemaria Escriva de Balaguer 1902-1975. São Paulo: Quadrante.

Queiruga, A. T. (2001). Do terror de Isaac ao Abbá de Jesus: por uma nova imagem de Deus. São Paulo: Paulinas.

Queiruga, A. T. (2003). Fim do cristianismo pré-moderno: desafios para um novo horizonte. São Paulo: Paulus.

Rey, F. G. (1999). La investigación cualitativa em Psicologia: rumbos y desafios. São Paulo: EDUC.

Rodriguez, P. et al. (1993). O Opus Dei na Igreja: introdução eclesiológica à vida e ao apostolado do Opus Dei (Magistra, n.6). Lisboa: Rei dos Livros.

Rondoni, D. (Org.). (1999). Comunhão e libertação: um movimento na Igreja. São Paulo: Sociedade Litterae Communionis.

Silva, R. A. S. L. (2000). Igreja comunhão e movimento dos focolares: a eclesiologia de comunhão como centro da espiritualidade e vida do movimento dos focolares. Dissertação de mestrado em Teologia Sistemática, não-publicada, Pontifícia Universidade Católica do Rio Grande do Sul, Porto Alegre.

Urquhart, G. (2002). A armada do Papa: os segredos e o poder nas novas seitas da Igreja Católica. Rio de Janeiro: Record.

Vicente, A. F. (1988). Ocaminho Neocatecumenal: um caminho de iniciação cristã (Comunidade Viva, n.17). Porto: Perpetuo Socorro.

Recebido em: 3/8/2005

Versão final reapresentada em: 6/12/2005

Aprovado em: 26/4/2006 